\title{
BEYOND PUBLIC MANAGEMENT THEORIES: THE CREATION OF PUBLIC VALUE THROUGH CO-PRODUCTION
}

\author{
Malang B.S. Bojang \\ ${ }^{1}$ Political Science and Public Administration Department, Faculty of Economics and Administrative \\ Sciences, Kocaeli University, Umuttepe Campus, Kocael, Turkey
}

\section{ARTICLE INFO}

Recieved: 24 December 2021 Revised: 11 February 2022 Accepted: 14 February 2022

Keywords: Co-production, public value, public sector, public value creation, public management theories

Corresponding Author: Malang B.S. Bojang

Email: malangbsbojang@gmail.com Copyright $\odot 2021$ by author(s)

This work is licensed under the Creative Commons Attribution International License (CC BY 4.0). http://creativecommons.org/licenses/ by/4.0/

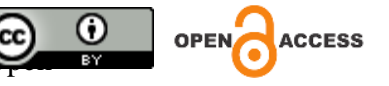

\begin{abstract}
Purpose: This paper presents a review of the role of co-production in the public sector and discusses how co-production can help public administrations to create better public value for contemporary society.

Approach/Methodology/Design: Employing a qualitative approach, this study builds on the strategic triangle which depicts public value generation in the public sector. This framework shows how and why co-production is more valuable than classical management theories when public value generation is concerned. Data for this study has been collected through databases searches. The study follows a disciplined process in conducting a literature review as suggested by Webster and Watson (2002)—using keyword searches in ProQuest and Google Scholar.

Findings: The paper argues that co-production can help to overcome the many limitations linked to traditional administration theories regarding public value creation. The results from the review indicate that co-production aim at improving the performance of the existing public services by actively involving service users in co-designing and improvement of public services. It shows how service experience can be integrated with the overall life experience of citizens.

Practical Implications: The study has both practical and theoretical implications. It contributes by identifying co-production as an alternative means for value creation in the public sector. This is significant for theory development and empirical research. For practitioners, co-production helps to evaluate the performance of their organizations effectively.

Originality/Value: Despite the significance of public value, few scholars pay attention to co-production as a means to generate public value. Co-production accounts for the need of the citizen in the production process of public value.
\end{abstract}

\section{INTRODUCTION}

The public sector plays a significant role in shaping modern society with its wicked and unruly problems. This is done through shifting from government to governance. Contemporary public administration aims to establish a plurilateral and collaborative approach to governance (Ju et al., 2019). The governance model for co-production could help deliver quality public services and at the same time meet the aspirations and preferences of citizens. From the public sector perspective, co-production ought to focus on the creation of public value and fulfilling the 
expectations of citizens (Cordella et al., 2018). Citizen participation has the potential to create public value for different service sector organizations. It improves the efficiency and effectiveness of public sector organizations, increases citizens' satisfaction, and enhances social values.

Co-production is currently one of the cornerstones of administration and policy reforms (Osborne et al., 2016). As an emerging paradigm, co-production accounts for the need of the citizen in the production process of public value. It is a term describing public participation in government mediated by e-petitioning, e-participation, or e-democracy (Cordella et al., 2018). Co-production should concern issues in the public sector to enhance quality service delivery to the citizens. In this study, co-production is the participation of service users in initiating, designing, producing, managing, and delivering quality public services (Osborne et al., 2016:640). Public organizations depend on the general society for policy initiation, implementation, and quality service delivery as the society depended upon them. It is a way to rationally involve the public in the production process as well as the quality delivery of public service in a cost-effective way. From the service management standpoint, co-production is a significant and inalienable component of service delivery. In other words, there is no quality delivery of service without co-production.

For the past decades, public management theories have evolved to a plethora of models and theories on how best to produce and deliver quality public services to the citizens. Public value emerges as one of the leading public management paradigms, shifting focus from efficiency to much broader outcomes for society in general (Benington, 2009; Bojang, 2020; Bonina \& Cordella, 2009; Moore, 1995; Prebble, 2018; Rutgers \& Overeem, 2014). From the public management perspective, public value deviates from the narrow focus on individualism to the collective benefits of the citizens. Traditional administration models and theories concentrated on efficiency and cost reduction which are most valued. To deliver societal needs, the public sector has to better understand what is socially desirable and vigorously respond to changes in social expectations (Cordella et al., 2018).

This review aims to examine the role of co-production in the public sector and discuss how coproduction can help public administrations to create better public value for contemporary society. Co-production aims to overcome the many limitations linked to traditional administration regarding public value generation. Therefore, the paper seeks to answer the question: How can public institutions benefit from co-production to better generate public value? Notably, this study has two research implications. From the perspective of public institutions, I empirically demonstrate co-production mechanisms to create public value through the citizen participation process. Public administration provides a new perspective that centers mainly on the value created by citizen participation. The rest of the paper is organized as follows. The next section presents the research gap, theoretical background, and the significance of the research. This is followed by a discussion on traditional administration theories, and their failures to create public value for the collective 'we'. Co-production, a new model for value generation is then discussed and a general insight of co-production in the public sector is highlighted. The study is concluded with theoretical and management implications and future research recommended. 


\section{Research Gap and Theoretical Background}

In the extant literature, scholars have discussed co-production in public sector organizations (Cordella et al., 2018; Osborne et al., 2016). Although these studies are insightful about user contribution in the co-designing of services, few discuss the administrative implication of coproduction and its ability to create public value in public organizations. Value generation in the service sector requires profound analysis within co-production discourse. Such discussion in the public sector is significant as co-production makes public organizations more effective and value-driven. It is a value-building approach within a given society. Coined by Harvard academics, public value is a broad and overarching concept in public administration, yet very elusive (Wang \& Christensen, 2017). A fundamental function of government is to generate public value - for instance, promoting growth, ensuring social justice and equality, promoting democracy, protecting the environment (Bojang, 2021; Moore, 1995). However, the public value concept is far from being fully explained and clarified. This lack of clarity hampers public value from a philosophical concept to a practical policy tool. Concepts like 'Public' and 'Value' are problematic and difficult to define. The articulation of what is valuable for society is controversial in policy space (Alford et al., 2016).

The theoretical framework of this study is the 'strategic triangle' which is the core idea of public value generation in the public sector. Scholars have reconfigured the strategic triangle into a management tool for describing, analyzing, evaluating managerial behavior and governance process. The public value paradigm is proclaimed to be the 'next big thing in public administration' (Talbot, 2017). The strategic triangle proposed by Moore (1995) encompassed three dimensions that must be aligned with each other (see Figure 1). The first dimension is the 'public value proposition' that the government ought to be producing. Public sector organizations should concentrate on value creation and meeting social outcomes for society. Secondly, public sector managers should actively be garnering authorization for their value proposition. The authorizing environment is not only limited to getting the nod from the minister but also other relevant stakeholders and actors which can include lawmakers, interest groups, regulators, clients, and by one means or another, the general public. Public managers need to stretch their influence and call into action all these groups. Getting such broad support to ensure legitimacy in the public value process. This implies that public managers should 'manage up and manage out' in public sector organizations (Alford et al., 2016).

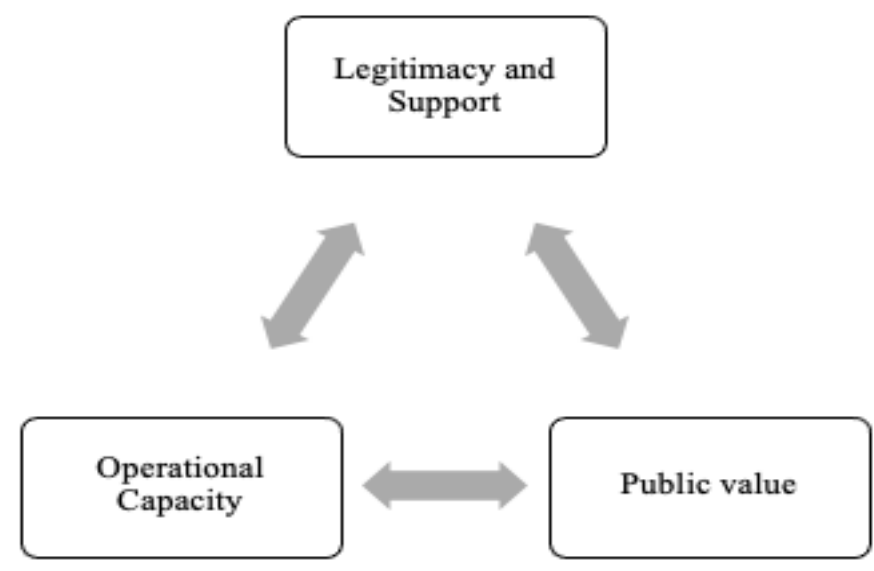

Figure 1. The strategic triangle of public value management, Moore (1955) 
The third dimension of the strategic triangle concerns the practicality of producing value. Having value proposition and support are not enough, mustering the administrative capacity to deliver value is required. Service managers are tasked to align resources, people, and other relevant actors to create a broader social outcome for society. The operational capacity is the focal point that requires coordination and collaboration between various organizations and agencies.

This study develops on the strategic triangle framework which depicts public value generation in organizations (Benington, 2009; Moore, 1995). This framework demonstrates the significance of co-production over classical management theories when value generation is concerned. The take-off point for this study is the operational/administrative capacity of public institutions. The capacity of these organizations aims to deliver both individual and societal outcomes (Cordella et al., 2018). The ongoing search for administrative efficiency has attached significance to the operational capacity of public institutions, to deliver quality public services and respond to the wicked problems in contemporary society. To solve problems, and meet citizens' desires, public institutions have depended on managerial tactics of bureaucratic logic and New Public Management (shortly, NPM) frameworks. For all its worth, the NPM was designed at leveraging administrative efficiency and improving institutional performances. From bureaucracy to modern management models, value generation has always been the core of public management.

\section{METHODOLOGY AND PROCEDURES}

The purpose of this paper is to examine the role of co-production in public institutions and discuss how to better generate public value through co-production. Co-production aims to overcome the many limitations linked to classical administration theories regarding public value creation. To meet the research goals, a qualitative review is adopted. This study builds on the 'strategic triangle' which is the core idea of public value management and value creation. The strategic triangle proposed by Moore (1995) encompassed three dimensions that need to be aligned with each other (see Figure 1). This framework is a significant step forward in enhancing and understanding the co-production process.

Employing a qualitative approach, data for this study has been collected through databases searches. The study follows a disciplined process in conducting a literature review as suggested by Webster and Watson (2002) — using keyword searches in ProQuest and Google Scholar. Keywords and phrases like 'co-production', 'co-production in the public sector', 'co-designing policy', 'public value', 'public value creation', 'public management theories' were used. From the databases search, articles, books, policy documents, and book chapters relevant to the topic under discussion were included.

\section{RESULTS AND DISCUSSION}

\section{Public Value and Public Management Theories}

Historically, public management complies with the continuous changes influenced by globalization (Bojang, 2020). These changes usher in different theories, paradigms, and models for the delivery of quality public services. The classical administration theories aimed to create and deliver value for the citizens. The administrative capacity of these models shape value generation in public organizations. For instance, within the public sector, bureaucracy and bureaucratic logic aim to produce and deliver public services. Bureaucracy can increase efficiency through administrative practices and actions (Cordella et al., 2018). Modern studies of bureaucracy date from Weber. Weber wishes to show the nature in which 
bureaucratic organization is a rational solution to the complexities of present-day problems. His theory on bureaucracy had a huge impact on organization theory and management practice. A key proponent of bureaucracy who grasps it as valuable was Max Weber himself. Weber is a key defendant of bureaucracy and has identified six central attributes in a bureaucracy which he argued would make governments efficient and work for public goods: clearly defined division of labor and authority, hierarchical structures of offices, well spellout guidelines suggesting performance standards, recruitment to offices based on knowledge and expertise, office-holding as a career and finally, duties and authority attached to positions, not individuals. He further argues that these elements specify how humans are recruited, distributed, and controlled within a bureaucratic organization and hence efficiency will follow. Weber (1946) proposed rationalization and standardization of administrative capacity to achieve efficiency.

We can argue that bureaucratic organizations value standardization and efficiency, thereby creating values such as impartiality, fairness, and equity in service delivery. These values shape the authorizing environment and thus bureaucracy generates social values (C. Bonina \& Cordella, 2008; C. M. Bonina \& Cordella, 2009; Cordella et al., 2018). Bureaucracy can both enhance and retard value generation in the public sector.

Like the Weberian bureaucracy, NPM is also designed to achieve optimal organizational efficiency. NPM perceived by some scholars as a 'management argument' and 'administrative philosophy' (Hood, 1991), is an administrative principle and a reform strategy that many Organization for Economic Cooperation and Development (OECD) nations executed in the 1980s (Hood, 1991). It is both structural, organizational, and managerial alteration in public institutions (Bojang, 2020, 2021). For others, NPM is a management doctrine focusing on organizational design and reinventing government (Osborne and Gaebler, 1992). Both bureaucracy and the NPM proposed alternative explanations in public administration, however, they both share the efficiency drive in public institutions. For both theories, public value is linked to the production process, and increasing organizational efficiency is all that matters in public institutions. The administrative capacity of bureaucracy and NPM failed to generate value in contemporary society-where public value is increasingly created by those who consume services (service users) rather than by those who produce them (Alford \& O'Flynn, 2009; Benington, 2009; Bojang, 2021; Cordella et al., 2018; Geuijen et al., 2016; Mark H. Moore, 1995). For classical models, public value is produced within public institutions and not those that consume public services.

Value generation is complex and multifaceted as is not only produced by government entities but also non-profit organizations (Bozeman, 2019; Jørgensen \& Bozeman, 2007). The classical administration theories focus more on efficiency, ignoring citizens in the value cycle. This separates value producers (public sector organizations) from those who consume services-i.e., citizens. On the other hand, public value management requires an organizational design that has the administrative capacity needed to satisfy the collective needs and wants of the public. It is significant to achieve efficiency but public organizations are not shaped by efficiency alone and that other public value goals ought to be achieved as well. For example, public institutions control, plan, and apply policies to decrease air pollution to provide a better and healthier environment for citizens. The success of these policies does not solely depend on administrative efficiency, but rather the collective action and reaction that citizens put in place to achieve the objectives of the policy. Therefore, it takes both the collective 'we' and the individual efforts to combat pollution. It is rational to argue that without citizens' input, value creation will be a daunting task for governments. Citizens are not only value consumers but are also active value producers for the greater good 
of society. They benefit from the public value and also value the services for the whole society as well.

Alternative solutions are much needed to generate a much better public value for society and to solve the wicked and unruly problems face by public management. As a developing paradigm, co-production is concerned with the participation and meeting the needs of service users in the production process. Citizens' collective expectations and aspirations help shape the performance and quality of services produced and delivered. The active or passive participation of the citizens/users of service in the creation and delivery process of public services is at the heart of co-production (Osborne et al., 2016).

For effective value generation, the administrative capacity capable of delivering socially desirable outcomes for society is required. Public organizations aiming for this venture should consider an alternative model for quality delivery of services to citizens' collective expectations. With the changing public values, co-production can better meet citizens' aspirations and offer effective and efficient services (Cordella et al., 2018; Osborne et al., 2016).

\section{Co-Production in the Public Sector: New Mode of Public Value Creation}

Today, public sector organizations are faced with the near-impossible task of creating conflicting values for citizens. Solving wicked problems is a daunting task for public managers due to the scale and magnitude of problems. These wicked problems can be solved by engaging the consumers in the co-design, implementation, and delivery of quality services (Geuijen et al., 2016). Scholars have underscored the need for service managers to commit to value generation and build trust in government (Tavares et al., 2021). As earlier mentioned, value is not necessarily created by the government but by a host of stakeholders and actors including citizens and communities. Politicians and service managers increasingly are expected to collaborate with relevant stakeholders to tackle the complex public problems that beset contemporary society (Crosby et al., 2016). Citizens can act as co-designers and coimplementers of values that they consume. Citizens have a lot to offer and their participation in value creation cannot be over-emphasized. Citizens perceived value creation as their involvement contributes to the betterment of public institutions and society in general (Ju et al., 2019).

Recently, co-production has become one of the most relevant approaches in public management because of its ability to identify the expectation of citizens in value creation. The public management literature underscores the relations between service producers and service users in administrative capacities. The citizens' contribution as co-producer during the service process is both unavoidable and critical for better performance. Co-production enhances the co-creation of public values including the satisfaction from the service, the impact of the service experience, and the extent to which it meets citizens' socio-economic needs (Osborne et al., 2016).

Public institutions tried to improve efficiency and cut costs in service delivery, and coproduction is largely seen as the possible solution. Co-production would improve the administrative capacity of the government. Co-production types like inner-sourcing, crowdsourcing, and open-sourcing are helpful in this regard (Cordella et al., 2018). These coproduction strategies help organizations to achieve internal efficiency and meet the social aspiration of citizens. Cost efficiency is not the only yardstick for performance but also meeting the collective expectations and benefits that are equitably managed and accessible to the public. To achieve this, governance structure and leadership commitment are necessary. 
Public value generation is complex because of the incompatible values that cannot be produced by traditional management theories. For example, a government may go against cost-efficiency to establish schools in rural areas for few children in line with value creation. By doing so, the government meets the social expectation of parents and their children. This vividly demonstrates that government services may not always be sustainable but aimed at a broader socio-economic goal reflected in public value. In public administration, cost efficiency is no more the standard for value creation, but rather co-production is the new norm (Cordella et al., 2018). The government should not only offer services but also have to make sure that such services are produced fairly and equitably. Co-production is more about improving the performance of the existing services by actively involving service users in codesigning, evaluating, and improving public services (Osborne et al., 2016). It shows how service experience can be integrated with the overall life experience of citizens. The central focus here is not only on service perse but also on how they are produced within the public sector.

Co-production needs to be done within the framework of public value creation. Coproduction has the potential to solve the wicked and unruly problems faced by public sector organizations. Citizens' engagement would facilitate a more effective account for the public value they contribute. Unlike the traditional theories of administration, citizens' participation is the core of co-production. Traditional administrative theories have been criticized for not meeting citizens' expectations. The ideal type of bureaucracy and market-focused NPM failed to deliver the anticipated services. According to Cordella et al., (2018), co-production allows citizens to co-create services that they want, at the same time increasing the value which is created by these services. Co-production has the potential to transform how public organizations work and the value they generate.

\section{CONCLUSION}

Public administration has been criticized for not creating enough value for society. This was the case for bureaucracy and NPM with more focus on efficiency of service production. The old management models indeed create value in the form of administrative efficiency while failing to meet the broader social outcomes. This value generation approach is obsolete and ineffective. The role of a public institution is to produce value and deliver quality public service to citizens, and anything less will defeat its overall purpose. In the co-production approach, service users are actively engaged in the production cycle of public value. The task for public sector managers is to find the right balance for value generation fairly and equitably. Co-production should be seen as a resource at the disposal of public sector managers to create the value of a much better service for the citizens. Further research is required to refine all three dimensions of the strategic triangle. This paper focuses explicitly on the operational/administrative capacity of public organizations. It does not address in detail other dimensions of the strategic triangle and from the broader perspective of citizens in the co-production cycle. This needs further serious consideration. A significant implication for public sector organizations is that co-production is not a normative good. It has the potential to lead to the co-destruction of value as much as to its co-creation. Furthermore, the discussion center on the role of citizens in the production of service. Equally, the role of service managers is important too. Co-production embraces the interaction between end-users of service and service managers. These are essential for the implementation of co-production in the public sector with the right governance and management models to solve the wicked problems faced by contemporary society. 


\section{Conflict of Interest}

The author declares no conflict of interest.

\section{Funding}

No funds received for carrying out this research.

\section{REFERENCES}

Alford, J., Douglas, S., Geuijen, K., \& 't Hart, P. (2016). Ventures in public value management: introduction to the symposium. Public Management Review, 19(5), 589-604. https://doi.org/10.1080/14719037.2016.1192160

Alford, J., \& O’Flynn, J. (2009). Making sense of public value: Concepts, critiques and emergent meanings. International Journal of Public Administration, 32(3-4), 171191. https://doi.org/10.1080/01900690902732731

Benington, J. (2009). Creating the public in order to create public value? International Journal of Public Administration, 32(3-4), 232-249. https://doi.org/10.1080/01900690902749578

Bojang, M. B. S. (2020). Beyond New Public Management Paradigm: The Public Value Paradigm and Its Implications for Public Sector Managers. Journal of Public Value and Administrative Insight, 3(2), 1-10. https://doi.org/10.31580/jpvai.v3i2.1381

Bojang, M. B. S. (2021). Appraising Public Value in the Public Sector: Re-evaluation of the Strategic Triangle. SEISENSE Journal of Management, 4(2), 1-10. https://doi.org/10.33215/sjom.v4i2.551

Bonina, C. M., \& Cordella, A. (2009). Public sector reforms and the notion of "public value": Implications for e-government deployment. 15th Americas Conference on Information Systems 2009, AMCIS 2009, 1, 469-476.

Bozeman, B. (2019). Public values: citizens' perspective. Public Management Review, 21(6), 817-838. https://doi.org/10.1080/14719037.2018.1529878

Cordella, A., Paletti, A., \& Shaikh, M. (2018). Renegotiating public value with coproduction. Creating and Capturing Value through Crowdsourcing, October, 181203. https://doi.org/10.1093/oso/9780198816225.003.0008

Crosby, B. C., 't Hart, P., \& Torfing, J. (2016). Public value creation through collaborative innovation. Public Management Review, 19(5), 655-669. https://doi.org/10.1080/14719037.2016.1192165

Geuijen, K., Moore, M., Cederquist, A., Ronning, R., \& van Twist, M. (2016). Creating public value in global wicked problems. Public Management Review, 19(5), 621639. https://doi.org/10.1080/14719037.2016.1192163

Hood, C. (1991). A Public Management for All Seasons ? Public Administration, 69(1), 319. http://dx.doi.org/10.1111/j.1467-9299.1991.tb00779.x

Jørgensen, T. B., \& Bozeman, B. (2007). Public Values: An Inventory. Administration \& Society, 39(3), 354-381. https://doi.org/10.1177/0095399707300703

Ju, J., Liu, L., \& Feng, Y. (2019). Public and private value in citizen participation in Egovernance: Evidence from a government-sponsored green commuting platform. 
Government Information Quarterly, 101400. https://doi.org/10.1016/j.giq.2019.101400

Moore, M. H. (1995). Creating-Public-Value-Strategic-Management-in-Government.pdf.

Osborne, S. P., Radnor, Z., \& Strokosch, K. (2016). Co-Production and the Co-Creation of Value in Public Services: A suitable case for treatment? Public Management Review, 18(5), 639-653. https://doi.org/10.1080/14719037.2015.1111927

Osborne, D. \& Gaebler, T. (1992). Reinventing Government: How the Entrepreneurial Spirit is Transforming Government. Reading Mass., Adison Wesley Publishing Company

Prebble, M. (2018). Is "we" singular? The nature of public value. American Review of Public Administration, 48(2), 103-118. https://doi.org/10.1177/0275074016671427

Rutgers, M. R., \& Overeem, P. (2014). Public Values in Public Administration. Journal of Public Administration Research and Theory, 24(3), 806-812. https://doi.org/10.1093/jopart/muu017

Talbot, C. R. (2017). Measuring Public Value - a competing values approach A competing values approach. March. https://doi.org/10.13140/RG.2.2.36824.90888

Tavares, G. M., Sobral, F., \& Wright, B. E. (2021). Commitment to Public Values, Charismatic Leadership Attributions, and Employee Turnover in Street-Level Bureaucracies. Journal of Public Administration Research and Theory, 31(3), 542560. https://doi.org/10.1093/jopart/muaa057

Wang, B., \& Christensen, T. (2017). The Open Public Value Account and Comprehensive Social Development: An Assessment of China and the United States. Administration and Society, 49(6), 852-881. https://doi.org/10.1177/0095399715587522

Weber, M. (1946). Bureaucracy. From Max Weber: Essays in Sociology. New York, Oxford University Press.

Webster, J., \& Watson, R. T. (2002). Analyzing the past to prepare for the future: writing a literature review. MIS Quarterly, 26(2), XIII-XXIII 